\title{
Legal Assistance for Accused and Victims in Austrian Pre-Trial Criminal Proceedings
}

\author{
Alois Birklbauer, Richard Soyer, Christoph Weber \\ Faculty of Law, Johannes Kepler University of Linz, Linz, Austria. \\ Email: richard.soyer@jku.at \\ Received September $18^{\text {th }}$, 2012; revised October $16^{\text {th }}$, 2012; accepted October $27^{\text {th }}, 2012$
}

\begin{abstract}
Based on two research projects this paper evaluates the legal assistance for accused and victims in pre-trial criminal proceedings in Austria after the implementation of a revised law on pre-trial proceedings in 2008. The research projects combined legal and empirical research. The project for scientific evaluation of the realization of the criminal procedure reform law (PEUS) analysed approx. 5000 pre-trial files and has additionally conducted 85 interviews with police officers, prosecutors, judges and lawyers. The results of the empirical research provide insight into which extent in practice in Austrian criminal proceedings the accused has access to legal advise. The paper comes to the conclusion that by strengthening victims' access to legal representation in Austrian criminal proceedings in numerous cases the actual division of power to influence the proceedings has shifted from the accused to the victim.
\end{abstract}

Keywords: Pre-Trial Criminal Procedure; Legal Assistance; Accused; Victim; Law in Practice

\section{Introduction}

According to the Austrian Code of Criminal Procedure (CCP) the accused and the victim have the right to legal advice. This right is important for law enforcement, especially at the beginning of the procedure, where the course for the further procedure is set. Police and public prosecutors are obliged to start pre-trial investigations, if they find sufficient indications that a criminal offence has been committed. The Austrian criminal procedure is based on the principle of objectivity and on the principle of ex-officio investigations (§ 3 CCP). Both the accused and the victim have the right to information upon the allegation and their rights (§§ 6 (2), 10 (2) CCP). The proper understanding of the function of the law enforcement agencies requires constant critical scrutinising of investigation steps, a task which is generally supported by the actions of legal advisers, e.g. by filing motions to admit further evidence.

In the course of two empirical research projects which have been carried out during the last years in Austria, the role of legal assistance at the beginning of pre-trial proceedings has been analysed. The project for scientific evaluation of the realization of the criminal procedure reform law (PEUS) analysed appr. 5000 pre-trial files and has additionally conducted 85 interviews with police officers, prosecutors, judges and lawyers [1,2].

The project Pre-trial Emergency Defence (PED) has investigated access to defence rights and legal assistance at the beginning of criminal proceedings in Germany, Croatia, Slovenia and Austria. Data was collected by means of questionnaires handed out to the parties to the proceedings (appr. 770 were returned). Furthermore, 86 interviews with policemen, prosecutors, judges, lawyers and in Austria also with accused have been conducted [3, 4].

The results of these empirical projects provide insight to which extent in practice in criminal proceedings the accused has access to a legal adviser. PEUS also explored to which extent victims make use of legal assistance, which may be provided to the victim free of charge within the legal framework (§§ 66 (2), 67 (2) CCP).

The PEUS results regarding the accused's and the victims' right to legal assistance as well as identified relations and special interactions shall be presented in the following.

\section{The Parties to the Proceedings and Their Right to Legal Assistance}

\subsection{The Right to Legal Assistance for the Accused-An Overview}

The right to information about his/her rights as well as the allegations ( $\$ 50 \mathrm{CCP}$ ) and in this context the right to bring in a defence lawyer ( $\$ 58 \mathrm{CCP}$ ) or, respectively, being provided with legal aid in the case of social indigence and/or if required "in the interests of justice" (§ 61 
(2) CCP), further the right to participate in certain investigative measures (§§ 150, 165 (2) CCP) are considered as the fundamental procedural rights of the accused. Furthermore, the right to make a statement ( $\$ 7 \mathrm{CCP}$ ), the right to file motions to admit evidence ( $\$ 55$ CCP) and the right to legal remedies pre-trial (§§ 67, 106, 108 CCP) as well as the right to appeal against the judgment (§§ $281 \mathrm{ff}$ CCP) should be named.

\subsection{The Right to Legal Assistance for the Victim-An Overview}

It should be noted that the CCP defines the term "victim" rather extensively (see $\S 65$ No. 1 CCP). Thus, victims are not only direct victims of violence or sexual criminal offences, but also indirect victims, meaning certain relatives of a killed person and anyone else who could have suffered a loss or damage due to the criminal offence or who could have been impaired in his/her legally protected interests. Based on this broad definition all natural persons and legal entities entitled to claim indemnification may be a victim according to the CCP.

$\S 66$ (1) CCP gives an overview of the most important rights, to which all different types of victims are entitled. Thus, the victim has the right to be represented by counsel (§ 73 CCP), the right to information about the subject of the procedure and his/her rights (§ 70 (1) CCP), the right to have access to the file ( $\$ 68 \mathrm{CCP}$ ), the right to participate in certain investigative measures ( $\S \S 150$, 165 (2) CCP), the right to pre-trial remedies (§§ 87, 106, 195 CCP) and to some extent also the right to appeal against the judgement. In 2008 the possibility for the victim to appeal for nullity against a verdict of not guilty was established within narrow limits (§ 282 (2) CCP). Especially this last remedy is not undisputed since it allows for two parties to the proceedings to challenge the verdict to the detriment of the defendant, thereby possibly distorting the balance of the procedure [1].

These central rights, which are applicable to all types of victims in the criminal procedure, have to be differentiated from the psycho-social and legal accompaniment (§ 66 (2) CPP) which is classified as special right exclusively of victims in the sense of $\S 65$ No. 1 lit. a and b CPP. No such provisions are made for the sole purpose to assert compensation claims. However, there is a "flaw" in the system of accompaniment during proceedings. Even though the law provides for a subjective right, it is lacking legal enforcement possibilities.

Certain private associations are funded annually by the Federal Ministry of Justice for the implementation of psycho-social and legal accompaniment during criminal proceedings. Their services, however, are limited to these monetary funds. Ultimately, victims do not have any means to enforce their right to legal accompaniment once these financial resources have been exhausted [5].

\section{Legal Assistance in Practice and Their Role in the Proceedings}

\subsection{Legal Adviser for the Accused}

According to the results of project PEUS less than 8\% of the accused were represented by a legal adviser. Thus, in the vast majority of cases there is no legal support (Table 1). There is, however, a remarkable difference between proceedings within the jurisdiction of district courts (" $\mathrm{B}$ AZ-proceedings") ${ }^{1}$ and those before regional courts ("Stproceedings"), but also in St-proceedings not even one fifth of all cases are supported by a lawyer.

These figures are significantly lower even when studying the number of consultations of a legal adviser in particular for the accused's questioning. Altogether not even $2 \%$ of all questionings of accused are made in the presence of a legal adviser. This figure stays as low as $3 \%$ in St-proceedings as well (see Table 2).

\subsection{Legal Adviser for the Victim}

$7.2 \%$ of the victims are represented by a legal adviser during investigative proceedings. In BAZ-proceedings the share of legal representation is higher on the victim's side than on the accused's whereas in St-proceedings the situation is inverted (see Table 3). The reason for this might be that in less servere areas of crime (e.g. bodily injury in street traffic) many insurance companies provide a legal adviser for the victim, since the proceedings are closely associated with their obligations to pay insurance benefits. Aside from that, the higher share of legal representation in BAZ-proceedings can also be explained by the fact that often corporate counsels enforce the victim's interests, should the victim be a legal entity rather than a natural person. The reason why victims as well as the accused are more likely to be represented in St- rather than BAZ-proceedings can be seen in the fact that the vast majority of serious violent and sex crimes fall within the jurisdiction of regional courts, where legal accompaniment is more common than within the jurisdiction of district courts.

\subsection{Legal Adviser for the Accused and the Victim in the Same Proceedings}

If you compare the relation between legal representation of the accused and the victim, you find some cases, in which the accused is represented by a lawyer during the investigative proceedings, whereas the victim is not (see Table 4). These cases amount to $12 \%$ in St-proceedings and $2.4 \%$ in BAZ-proceedings. On the other hand, in more than $7 \%$ of St-proceedings the victim is represented, while the accused has no legal adviser. In BAZ-proceedings this share accounts for $4.5 \%$. That means that es-

${ }^{1}$ These are criminal actions with a maximum jail term of up to one year (see $\S 30 \mathrm{CPP}$ ). 
Table 1. Accused is represented by a lawyer (percentages in columns).

\begin{tabular}{|c|c|c|c|}
\hline Are there indications in the file, that the accused was represented by a legal adviser? & BAZ & St & Total \\
\hline Yes & 3.7 & 18.1 & 7.9 \\
\hline No & 96.3 & 81.9 & 92.1 \\
\hline Total & 100.0 (3338) & 100.0 (1352) & $100.0(4690)$ \\
\hline
\end{tabular}

Differences between BAZ- and St-proceedings are significant at $\mathrm{p}<0.001 ; \mathrm{N}=$ values in brackets.

Table 2. Presence of a legal adviser during the questioning of an accused (percentages in columns).

\begin{tabular}{ccccc}
\hline Defence lawyer present during questioning & BAZ & St & Total & 1.8 \\
\hline Yes & 1.2 & 3.0 & 98.2 & 97.0 \\
No & 98.8 & $100.0(2879)$ & $100.0(1351)$ & $100.0(4230)$ \\
\hline
\end{tabular}

Differences between BAZ- and St-proceedings are significant at $\mathrm{p}<0.001$; number of questionings in total = values in brackets.

Table 3. Victim represented by legal adviser (percentages in columns).

\begin{tabular}{ccccc}
\hline Are there any indications in the file, that the victim is represented by a legal adviser? & BAZ & St & Total \\
\hline Yes & 5.8 & 10.9 & 7.2 \\
No & 94.4 & 89.1 & 92.3 \\
Total & $100.0(2272)$ & $100.0(1032)$ & $100.0(3766)$ \\
\hline
\end{tabular}

Differences between BAZ- and St-proceedings are significant at $\mathrm{p}<0.001$; Cases with victims = values in brackets.

Table 4. Representation of victims and accused by lawyers in cases with only one accused (total percentage).

\begin{tabular}{|c|c|c|c|c|c|c|}
\hline & \multicolumn{3}{|c|}{ BAZ } & \multicolumn{3}{|c|}{ St } \\
\hline \multirow[t]{2}{*}{ Accused represented by lawyer } & \multicolumn{3}{|c|}{ Victim represented by lawyer } & \multicolumn{3}{|c|}{ Victim represented by lawyer } \\
\hline & Yes & No & Total & Yes & No & Total \\
\hline Yes & 1.0 & 2.4 & 3.4 & 3.6 & 12.1 & 15.6 \\
\hline No & 4.5 & 92.2 & 96.6 & 7.1 & 77.3 & 84.4 \\
\hline Total & 5.5 & 94.5 & $100.0(2321)$ & 10.6 & 89.4 & $100.0(780)$ \\
\hline
\end{tabular}

Cases with victims and only one accused = values in brackets.

pecially in St-proceedings there are some cases, in which the unrepresented accused is facing a represented victim. This occurs even more so in BAZ-proceedings, which again can be explained with corporate counsels.

\subsection{Legal Advisers and Access to Files}

It is striking that in $99 \%$ of all cases the accused did not make use of his right to inspect the files if he/she was unrepresented (see Table 5). If the accused had a legal adviser, access to the file has been requested in only one third of all cases of St-proceedings according to project PEUS. This surprising result, however, has been put into perspective when interviews with legal practitioners have shown that access to the file is not always documented as thoroughly as should be. At some public prosecutor's offices only the refusal of access to files is being recorded but not if the right is being granted.
Likewise, the evaluation of the inspection of files by victims and their legal advisers shows that in more than $90 \%$ of all 69 cases access to files has been requested by the legal adviser rather than by the victim (see Table 6).

\subsection{Legal Remedies in Pre-Trial Investigative Proceedings}

It has been found that remedies do not occur frequently in pre-trial investigative proceedings. If remedial actions are taken, it is mainly done so by the legal adviser. The Table analysis of nearly 5000 investigative proceedings has shown that in only two of those 5000 cases objections have been raised against investigative measures of the police or the prosecution ( $§ 106$ CPP) and both have been raised by a lawyer. Complaints have been made in eleven cases and again more than half of those have been lodged by a lawyer. These findings lead to the assumption that 
Table 5. Access to files by represented accused (percentages in rows).

\begin{tabular}{cccccccc}
\hline $\begin{array}{c}\text { Accused } \\
\text { represented by a } \\
\text { legal adviser }\end{array}$ & \multicolumn{3}{c}{ BAZ } & \multicolumn{3}{c}{ St } \\
\hline & \multicolumn{4}{c}{ Access to files requested } & \multicolumn{2}{c}{ Access to files requested } \\
& Yes & No & Total & Yes & No & Total \\
Yes & 64.5 & 35.5 & $100.0(124)$ & 37.2 & 62.8 & $100.0(242)$ \\
No & 0.5 & 99.5 & $100.0(3210)$ & 0.8 & 99.2 & $100.0(1096)$ \\
Total & 2.9 & 97.1 & $100.0(3334)$ & 7.4 & 92.6 & $100.0(1338)$ \\
\hline
\end{tabular}

For BAZ- as well as ST-proceedings the differences between represented and non-represented accused are significant at $\mathrm{p}<0.001, \mathrm{~N} 0$ values in brackets

Table 6. Access to files by the victim and their legal adviser (percentages in columns).

\begin{tabular}{cccc}
\hline Who requested access to files? & BAZ & St & Total \\
\hline Victim & 2.4 & 10.7 & 4.3 \\
Legal adviser & 97.6 & 89.3 & 95.7 \\
& 100.0 & 100.0 & 100.0 \\
Total & $(45)$ & $(25)$ & $(69)$ \\
\hline
\end{tabular}

Differences between BAZ- and St-proceedings are not significant, $\mathrm{p}>0.05$; number of access to files $=$ values in brackets.

there is a strong connection between legal representation and the taking of remedies.

If this is true, the fact that in some cases the victim is being represented whereas the accused is not, takes on new significance.

\section{Conclusions and Crime Policy Proposals}

When strengthening the rights of victims, it has to be emphasized that the main interest of criminal and criminal procedure law is not to satisfy the victim's interests, but to clarify crimes and react to them. Indirectly, criminal law serves as a means to control the actions of all members of society.

The principle of fairness in criminal procedure law demands to grant the accused possibilities to defend him/ her against the public prosecutor's actions (Article 6 EMRK).

In order to keep the prosecutorial/police power of the state tolerable, the law enforcement agencies are required to maintain outmost objectivity and the principle of examination of the facts by the office of its own motion (exofficio investigation) and the "manuduction obligation" apply.

When expanding the rights of victims during the last years the legislator has tried to keep a certain "balance in relation to the rights of the accused". The different op- tions to access legal support, which can be explained for example by the fact that the accused has the right to legal representation only if he/she is eligible due to his/her social needs whereas the victim may be granted legal accompaniment regardless of these social requirements, ${ }^{2}$ have led to the fact that in numerous cases the actual division of power to influence the proceedings has shifted from the accused to the victim.

Due to the correlation between the exercise of procedural rights and the use of a legal adviser, we have to assume that ultimately the "manuduction obligation" of the law enforcement agencies cannot assure procedural fairness in the sense of a balance of interests. In order to restore the balance of all parties to the procedure, access to legal advisers has to be improved for the accused. In the interest of the proper administration of justice, access to legal aid has to be facilitated in a way that at least in cases where the victim is represented in pre-trial investigative proceedings the accused should be granted legal advice, too, if he/she is eligible due to his/her social needs. In addition to that, cases of necessary defence (or legal aid) in difficult cases should be extended to pre-trial investigative proceedings.

In the course of the planned reform of the main and appellate procedures in Austria, where a possible extension of the rights of victims will be discussed, it should be paid particular attention to the balance between the parties to the procedure. Thus, the emphasis should be put on the "care for the victim during the proceedings" rather than the victim's right to remedies to enforce an "alleged right to inflict punishment".

\section{REFERENCES}

[1] A. Birklbauer, C. Weber, B. Starzer, W. Stangl and R. Soyer, "Die Rechtspraxis des Ermittlungsverfahrens nach der Strafprozessreform. Zusammenfassung der Ergebnisse einer rechtstatsächlichen Untersuchung," Österreichische Juristenzeitung, Vol. 66, No. 19, 2011, pp. 852-867.

[2] A. Birklbauer, W. Stangl, R. Soyer, C. Weber, B. Starzer, H. Hirtenlehner, R. Gombots and W. Hammerschick, "Die Rechtspraxis des Ermittlungsverfahrens nach der Strafprozessreform. Eine rechtstatsächliche Untersuchung,” Neuer Wissenschaftlicher Verlag, Vienna and Graz, 2011.

[3] S. Schumann, K. Bruckmüller, and R. Soyer, "Pre-Trial Emergency Defence,” Neuer Wissenschaftlicher Verlag, Intersentia, Vienna, Graz and Antwerp, 2012.

[4] S. Schumann, K. Bruckmüller and R. Soyer, "Assessing Pre-Trial Access to Legal Advice-Results of a Comparative Legal and Empirical Study," New Journal of European Criminal Law, Vol. 3, No. 1, 2012, pp. 31-48.

[5] R. Kier, “§ 66 StPO,” In: H. Fuchs and E. Ratz, Eds., Wiener Kommentar zur Strafprozessordnung, Manz, Vienna, 2009. 